Мальцева О.С.

ФГБУ «Национальный медицинский исследовательский центр акушерства, гинекологии и перинатологии имени академика В.И. Кулакова» МЗ РФ (г.Москва)

\title{
ПЕДИАТРИЯ И НЕОНАТОЛОГИЯ В ЭКСТРЕМАЛЬНЫХ УСЛОВИЯХ (АЛГОРИТМЫ ДЕЙСТВИЯ ПРИ ЧС)
}

\section{АКТУАЛЬНОСТЬ}

Обеспечение безопасности детей имеет не только медицинское, но и стратегическое значение. История знает печальные примеры: в июле 1941 года более 160 тысяч детей без родителей эвакуировали из Ленинграда в южные районы области, прямо навстречу наступающим фашистам. Около половины детей были дошкольного возраста, при этом один взрослый обеспечивал безопасность 50 детей, медицинское обслуживание складывалось из расчёта «одна медсестра на 300 детей, один врач - на 500». Дети находились на узловых железнодорожных станциях, попадали под бомбёжки и налёты, погибали, пропадали без вести, а родители, узнав о трагедии, покидали рабочие места и самостоятельно отправлялись на поиски. Впоследствии родители, потерявшие своих детей, требовали судить организаторов поспешной и неправильной, по их мнению, эвакуации. Однако имеются документальные свидетельства о том, что мероприятие было осуществлено по довоенному плану. Наиболее вероятным противником считалась Финляндия, угроза Ленинграду ожидалась с севера, эвакуация планировалась на юг. У властей не было никакой импровизации. Когда началась война, ряд чиновников сомневались В правильности выбранного направления, но боялись проявить инициативу.

На сегодняшний, мирный день ситуация далека от идеальной. Есть три нормативных акта, регламентирующих деятельность медицинской службы при чрезвычайной ситуации. Один из них совсем свежий - конец 2020 года. И ни в одном из них не выделено, что делать при большом количестве пострадавших детей. Нет акта-инструкции, прочитав который, можно получить чёткий план действий. В то же время, по данным Генеральной
Прокуратуры РФ в нашей стране десятки тысяч детей умирают ежегодно от травм, убийств, самоубийств, отравлений. Несчастные случаи вызывают у детей и подростков больше смертей и тяжелых травм, чем все заболевания вместе взятые. При этом, опыт оказания медицинской помощи детям в чрезвычайных ситуациях в нашей стране проанализирован весьма скромно и касается, в основном, хирургической помощи.

\section{ЦЕЛЬ}

Формирование алгоритма действий врача экстренной специальности (анестезиолога-реаниматолога, хирурга) на догоспитальном этапе, в условиях, когда пострадавшие - дети в большом количестве.

\section{РЕЗУЛЬТАТЫ И ОБСУЖДЕНИЕ}

Первое, наиболее важное действие понять, с каким количеством пострадавших предстоит работать. При возможности, это необходимо сделать заранее, до прибытия на место происшествия. При природных ЧС количество пострадавших детей соотносится с процентом детского населения, проживающим на данной территории. При техногенных- зависит от места, времени возникновения и её характера. При социальных - может достигать $45 \%$ от общего числа пострадавших.

Второе действие при работе вне лечебных учреждений - убедиться в собственной безопасности и зонировать место проведения спасательных работ.

В красной зоне факторы окружающей среды прямо и непосредственно угрожают жизни людей. Медицинская помощь не оказывается, проводится экстренная эвакуация силами специалистов, имеющих соответствующую подготовку и экипировку.

В жёлтой зоне опасные факторы могут быть полностью или частично нейтрали- 


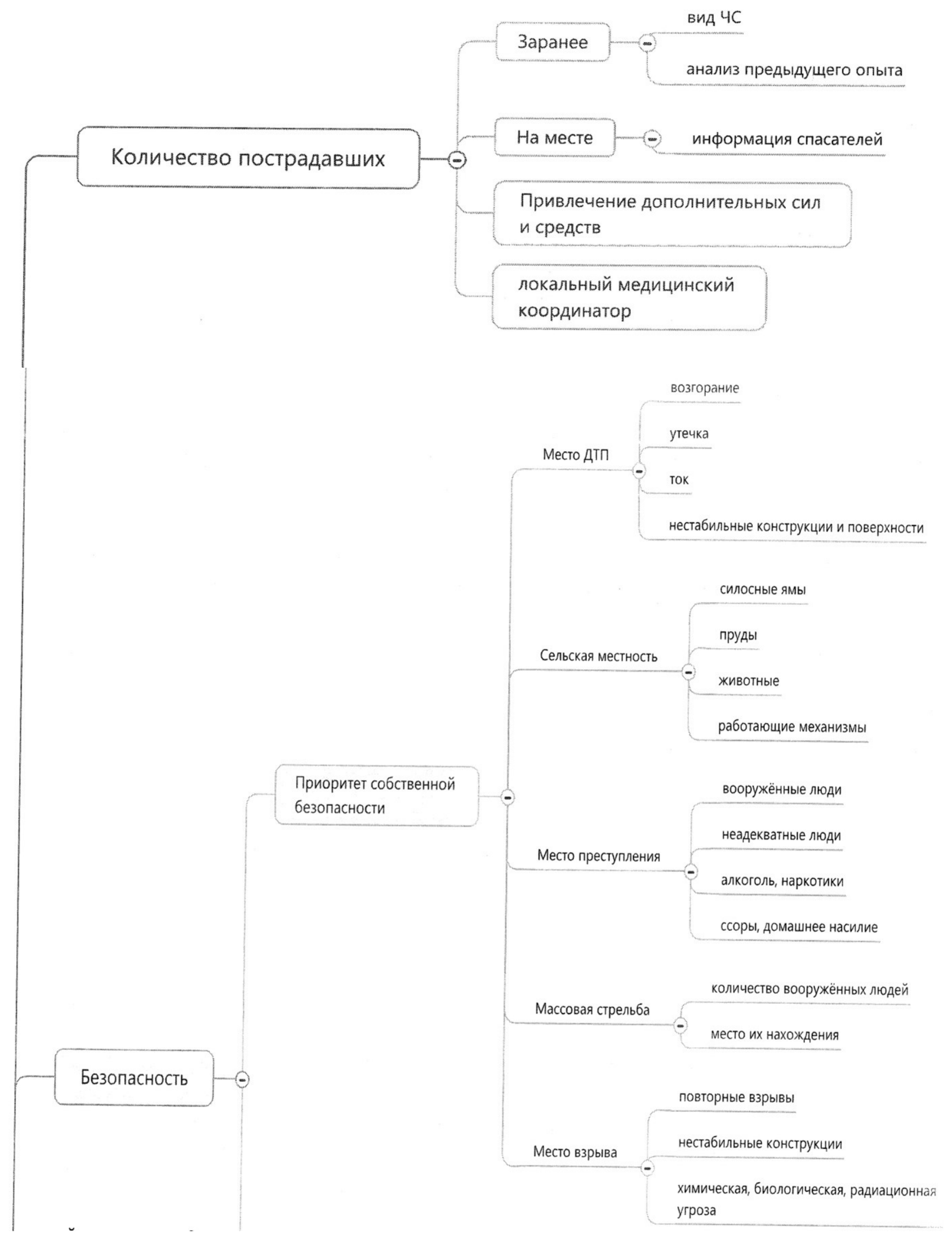




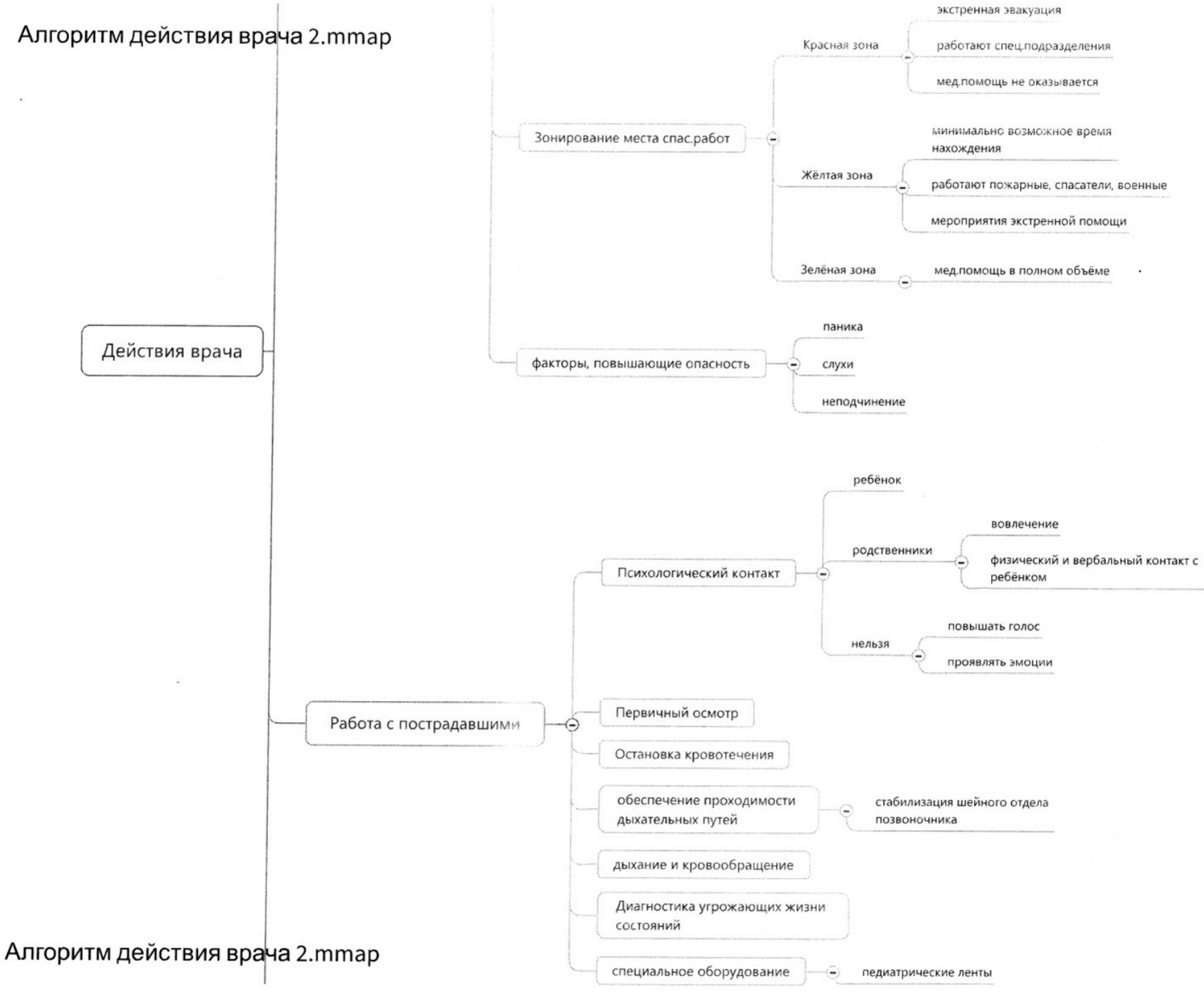

Алгоритм действия врача 2.mmap

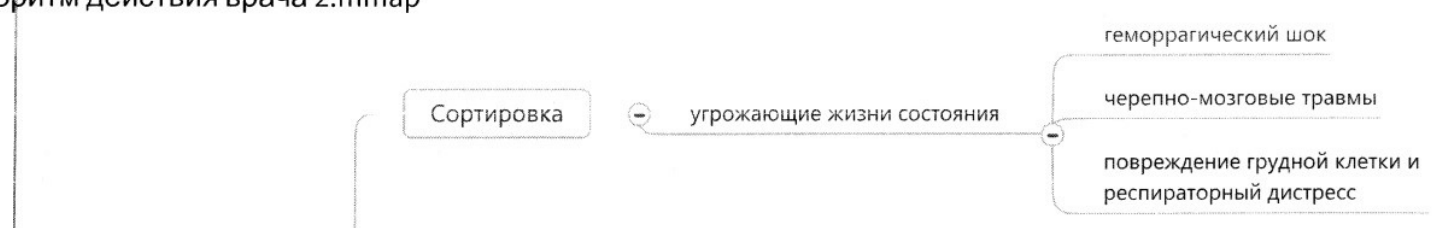

ближайшее отделение неотложной помощи

региональный центр детской травмы

частным автотранспортом
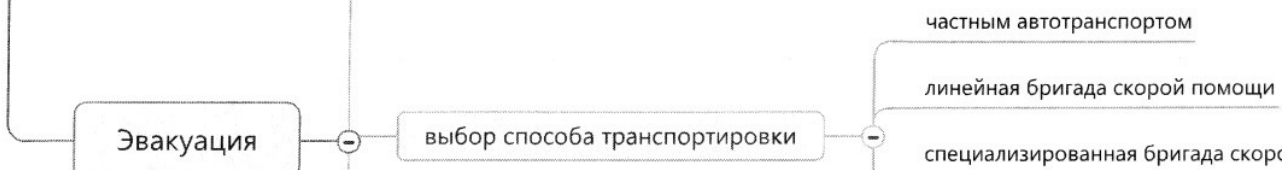

выбор способа транспортировки

специализированная бригада скорой помощи

санитарная авиация

оценка времени транспортировки

Подготовка к эвакуации

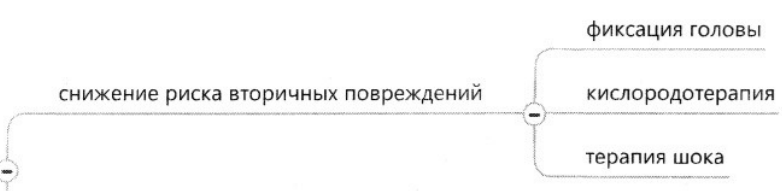

транспортировка в детском автокресле 
зованы доступными средствами защиты. Тем не менее, необходимо минимизировать время нахождения пострадавших в этой зоне, поэтому выполняются только жизнеспасающие мероприятия, как правило, силами спасателей, пожарных, военных.

Зелёная зона считается условно безопасной, факторы окружающей среды не оказывают выраженного негативного воздействия на тех, кто в ней находится. Помощь оказывают медработники в полном объёме.

Также необходимо предотвратить факторы, повышающие опасность внешнего воздействия: панику, распространение ложных слухов, неповиновение должностным лицам. Кратко охарактеризовать этот пункт помогает поговорка спасателей: «Количество пострадавших увеличивается на число не подумавших».

Третьим действием, как отечественные, так и зарубежные специалисты считают установление психологического контакта с пострадавшим ребёнком. Если есть члены семьи, необходимо заслужить их доверие и вовлечь в процесс помощи ребёнку. После чего необходимо провести осмотр и определить угрожающие жизни состояния и необходимость экстренной транспортировки в стационар. В педиатрической практике к таким состояниям относятся геморрагический шок, черепно-мозговые травмы, повреждение грудной клетки и респираторный дистресс.

Четвёртое действие - сортировка пострадавших, проведение жизнеспасающих мероприятий, определение способа медицинской эвакуации и подготовки к ней.

На всех этапах работы необходимо помнить, что дети - это не маленькие взрослые, знать анатомо-физиологические особенности детского организма и применять их на практике. У детей возникают иные, чем у взрослых повреждения и они по-другому на них реагируют, психологически и физически.

$$
\text { ВыВОДы }
$$

Таким образом, предложены алгоритм оказания помощи при ЧС у детей.
Сведения об авторах

Мальцева О.С.

врач анестезиолог-реаниматолог 